\title{
Social Media Usage and Impacts on the 2019 General Elections in Nigeria
}

\author{
Adesola Olowokere $^{1} \quad$ Susan Audu-Bako ${ }^{2}$ \\ Institute for Peace and Conflict Resolution (IPCR), 496,Abogo Largema Street \\ Central Business District, Abuja, Nigeria
}

\begin{abstract}
There have been controversial opinions on the role of the social media in elections. Some scholars have argued that the social media creates the platform for all to be part of democratic governance through public opinions, while others think otherwise. This study investigated the usage and impact of social media on the 2019 general elections. The study adopts primary and secondary methods of data collection. Findings from the study revealed that social media was used to inform and mobilize voters by various stakeholders during the 2019 elections. Also, findings indicated that the social media has the potential to add value to subsequent elections in Nigeria. It is therefore recommended that social media should be encouraged in political mobilization and participation of citizens considering its unique advantages to democratic consolidation in Nigeria.
\end{abstract}

Keywords: Elections, social media, voters

DOI: $10.7176 / \mathrm{IAGS} / 74-03$

Publication date:July $31^{\text {st }} 2019$

\section{Introduction}

According to Owoyemi (2018:2), since the beginning of the modern press in the early 18th century, it has been observed that writers, politicians, statesmen, scholars and media practitioners have attributed certain fundamental roles to the press as an institution. This becomes significant to journalism as a profession that occupies important positions in development and survival of a nation. Development in any nation is predicated on the quality of information dissemination. The reason is that information is power and essential to human existence. Bearing this in mind, Kuusik (2015) says information is power and can impact on public discourse. This gives credence to the claim of a United Nations staff, David Wimhurst in Bamgbose (2012:36) that:

\section{"The need for information is paralleled to the need for food, shelter, water, health care and so on. It can cut right through the rumours and the hostile propaganda that often swirl around and through conflict situations. The population generally do not know exactly what to believe. So if we can get out exact information to everyone on single clear report which is truthful that...is a net benefit to peace process"}

The media as an essential tool for increased democratic expectation and conflict resolution is a platform that can be employed for information and sensitization of the people, and can as well influence the activities of the government in the light of genuine leadership in public space (Nwagbara, 2010). Therefore, the press cannot afford to engage in unprofessional conducts, to become irresponsible or insensitive to the socio-cultural and political inclination of the people in its duties. Citing Lipman (1922), Sidney (1975:219) argues that "information is power and the more the people enjoy it, the more the power is circulated". He adds that the extent of the press freedom will determine the level to which it can effectively perform the role of watchdog over the conduct of public affairs.

According to Kaur and Kaur (2013), the rise of the internet in the early 1990s, has led to the increase in the world's networked population. The networked population has greater access to information, more opportunities to engage in public speech and a better ability to undertake united action. Social media has become a fact of life for individuals, involving many actors -- regular citizens, activists, non-governmental organizations, telecommunications firms, software providers, and government agencies and governments at large. Social media has emerged as a major tool where citizens are able to talk about the issues of day to day life and also of national importance. In 21st century, Facebook, Twitter and YouTube are not just innovations in the internet world, but are fast emerging as influencers and opinion creators (Ibid).

Kaplan and Haenlein (2010) define social media as "a group of Internet-based applications that build on the ideological and technological foundations of Web2.0, and that allow the creation and exchange of user-generated content." A social networking service is a platform to build social networks. These social network services are web based and these provide means for users to interact over the Internet .Social networking sites allow users to share ideas, pictures, posts, activities, events, and interests with people in their network. Thus, social media is a two-way avenue that doesn't just give you information, but interacts with you while giving you that information and enables interaction with other visitors also. 
General elections in Nigeria are becoming characterized by dissatisfaction exhibited by candidates, voters and observers including the electoral body (the Independent National Electoral Commission, INEC). The elections were trailed by complaints of irregularities such as disenfranchisement of prospective voters, snatching of ballot boxes from election officials and stuffing of the boxes with invalid ballot papers, as well as allegations of collusion between election officials and politicians to alter election results and subvert popular mandate (Aleyomi and Ajekaiye, 2014, Ibrahim and Ibeanu, 2009:6). The flaws that characterized the conduct of the 2007 elections in Nigeria severely dented the integrity of the elections and triggered demands for freer, fairer, and more transparent elections. The traditional media which includes: TV, Radio and Print have not lived up to expectations in terms of making genuine information available to the electorate before, during, and even after elections. One of the reasons for this is that most these traditional media are owned and controlled by the political elites in Nigeria, thus, the need for a shift to a more interactive media that allows for user-to-user generated contents which has eliminated the gate-keeping and agenda setting monopoly of the traditional media. The relevance of this study lies in its timeliness and recency (2019 general elections which is the case study of this research), because events during the elections period showed that social media platforms are very essential in the success of modern elections, survival and sustenance of democracy in the multi-political cum religious crisis-ridden African continent of which Nigeria is not left out. According to Aleyomi and Ajekaiye, (2014), the only way to have a legitimate government is to allow the electorate to decide who leads them; this can only be done through participation, and the social media provides one of the platforms for active participation in political affairs of one's country. Against this background, this research work investigated the usage and impacts of social media on voters in Nigeria using the 2019 general elections as case study.

\subsection{Research Questions}

In order to put this study in perspective, the following research questions were formulated as guide posts:

1. Which stakeholders reached you through the social media during the 2019 General Elections?

2. Did the social media contribute to the peaceful and successful conduct of 2019 General Elections?

3. How can the social media be used to add value to subsequent elections in Nigeria?

\subsection{Aim and Objectives of the Study}

The primary aim of this study was to investigate the usage and impact of social media on voters in Nigeria using 2019 general elections as case study, specifically, the study sought to:

1. Identify the stakeholders that utilized the social media in reaching respondents during the 2019 General Elections

2. Examine the contributions of the social media to the peaceful and successful conduct of the 2019 General Elections

3. Suggest how the social media can be used to add value to subsequent elections in Nigeria.

\subsection{Study Methodology}

The research methodology for this study is descriptive design. The researchers used survey method. The population of this study is a cross section of Nigerians resident in the Federal Capital Territory, Abuja. Consequently, questionnaire was deployed in collecting primary data for the study with 18 years and above being the acceptable age bracket of respondents. The FCT is chosen as the geographical scope of the study because it is the center of Nigeria and is the administrative headquarters of Nigeria. As the federal capital, FCT is where all ethnic groups can be found both in the city and the suburbs. Secondly, it has a high percentage of youths who use the social media.

\section{Conceptual clarifications}

\subsection{Social Media}

The term "Social Media" has been defined in different ways by its users. For instance, Kaplan and Haenlein (2010:9) define social media as "a group of internet-based applications that build on the ideological and technological foundations of Web 2.0 and that allow the creation and exchange of user-generated content". It includes web-based and mobile based technologies that are used to turn communication into interactive dialogue among individuals, organizations, and communities. Typical examples of social media platforms include websites such as Facebook, Twitter, Instagram, Skype, Zoom, YouTube and the interactive options on these websites, such as the "re-tweeting" option on Twitter. These instruments are referred to as media because they are tools which can also be used for the storage and dissemination of information. However, unlike the traditional media like Television and Radio, most of the social media tools allow their users to interact as "retwitting" on Twitter and "comment" options on Facebook illustrate.

Looking at social media from a more practical point of view, Sweetser and Lariscy (2008: 179) define social media as a "read-write Web", where the online audience moves beyond passive viewing of Web content to 
actually contributing to the content". One thing that is common in the definitions of social media reviewed in this work is the view that it is based on user-generated participation. The opportunity to enjoy user-to-user interaction distinguishes social media from the traditional media which is characterized by top-down news dissemination arrangement (Clark and Aufderheide, 2009:28). Another attribute of the social media which distinguishes it from the traditional media is the choice it accords its users. Choice enables people to access the information they like to learn about through the social media, eliminating the gatekeeper role of traditional media. On one hand, the choice offered by social media reduces the shared experience that viewers of particular traditional media channels usually have; on the other hand, it creates a network of individuals with like interests and similar preferences.

Two primary tools that have enabled people to socialize and connect with each other online are social networking sites and electronic messaging. More than half of America's teens and young adults send electronic messages and use social networking sites, and more than one-third of all internet users engage in these activities (Jones and Fox, 2009:33). In Nigeria, internet users are estimated, as at October 2014 to be 67,101,452 with 16\% growth rate when compared with the 2013 figure, and is $2.30 \%$ of the country's share of the world internet users (Internet Live Stats, 2014). Nigeria is also the third most active African country on twitter (Mejabi and Fagbule, 2014). Most people who use social media tools access them mainly through computers and mobile devices such as phones, tablets and personal computers. Analysts suggest that majority of phone purchases in the coming years will be more for using online networks rather than making phone calls (Baekdal, 2008:16). Politicians in Nigeria are joining the online community to communicate with their audiences because they believe they are a key demographic who shape and influence perception. Thus, phone communication is now tending toward oneto-many sharing rather than the usual one-to-one conversation. Nevertheless, there is no comprehensive knowledge of their activities as well as how this form of media can impact on voters in terms of mobilization and participation in Nigeria electoral process.

Social media technologies take on different forms including magazines, internet forums, weblogs, social blogs, podcasts, pictures, and video. Considering that social media come in diverse forms, Kaplan and Haenlein (2010:5) tried to classify social media into six distinct categories:

1. Collaborative projects (for example Wikipedia)

2. Blogs and Microblogs (for example Twitter)

3. Content communities (for example YouTube)

4. Social networking sites (for example Facebook)

5. Virtual game worlds (for example World of Warcraft)

6. Virtual social worlds (for example Second Life)

Out of these six categories of social media tools, three categories (blogs and micro blogs, content communities, and social networking sites) are the ones that are most relevant to the application of social media in the electoral process. In the process of political communication, there has been strong intermediation between the traditional media and the three categories of social media mentioned above. Traditional media channels, particularly television and newspapers, try to expand their reach by using social media platforms for news broadcast. In Nigeria for example, many newspapers like Guardian, Vanguard, Daily Trust, and This Day as well as television stations like Channels, have Facebook and Twitter accounts.

\section{Literature Review}

Arthur (2012:57) asserts that social media have great potential for encouraging collaborative political participation. Accessible social media platforms offer ordinary citizens the opportunity to interact more directly and actively with their political systems. Social media tools also possess the potential to allow diaspora communities to get involved in social-political processes. People engage in social media for various reasons which include to air their views and express (in some cases) anger and dissatisfaction. Mobilizing citizens to become engaged in politics is more than getting people out to vote at a poll on Election Day. Various Nigerian political actors and aspirants who are engaged in electoral processes are increasingly using social media platforms such as Facebook, Twitter, Instagram, YouTube and blogs in their campaigns. Political parties and independent political advocacy and interest groups have recently used Facebook, Twitter and political blogs as mediating platforms to engage citizens. Similarly, citizens have employed social media to participate in the electoral process. There are some pertinent examples of social media being widely used across Nigeria, most especially in the Fourth Republic to encourage citizens' political involvement. It is widely known that running election campaigns through social media platforms is a tactic that has been successfully employed in developed countries.

For example, Former US President Barack Obama ran a widely popular election campaign in 2008 that employed social media to good effect. In the U.S., the 2008 election of Barack Obama as President reflected unprecedented use of social media in a political campaign. The Obama campaign served as a stunning demonstration of a skilled team's use of widely available tools. The Obama campaign participated actively in 
more than 15 social networks and had 5 million active supporters through these media (Aleyomi and Ajakaiye, 2014). Likewise, President Donald Trump of the United States is a popular and daily user of Twitter to communicate to his political base and American audience. Also, President Goodluck Jonathan of Nigeria successfully utilized Facebook and Bulk SMS to interact with Nigerian citizens during the 2011 presidential elections. Jonathan even took the unprecedented decision of announcing his presidential candidacy on Facebook. The bid was announced on 15 September 2010 to his 217 000-plus fans through his Facebook page. By Election Day on 16 April 2011, Jonathan had over half a million fans on Facebook (Ibid).

In Nigeria's electoral process, social media tools were not only employed for political campaigns but also, various institutions involved in the elections also conducted their own social media initiatives. Institutions such as the Independent National Electoral Commission (INEC), political parties like the Peoples Democratic Party (PDP), All Progressive Congress, (APC) and others, candidates, media houses and civil society groups engaged with citizens on various social media platforms. During the month-long election process in April 2011, INEC posted almost 4000 tweets, many in response to voters ${ }^{\text {ee }}$ queries; a report on the role played by social media platforms during the electoral process revealed that Twitter ultimately proved to be the most efficient way to interact with INEC (op.cit). Similarly, during the election, the Nigerian mainstream media struck a relationship with social media platforms that enhanced both citizens' participation and professional journalistic practices. Journalists from various media organizations interacted with citizens on Facebook and the citizens' contributions informed the journalists' questions during interviews and debates with aspirants and institutions such as INEC.

Jega (cited in Amuchie, 2012:90) also agrees that the use of social media during the 2011 elections enhanced transparency in the electoral process and made INEC more accountable to the public in the conduct of elections. The importance of the above medium for citizens' political mobilization and participation notwithstanding, the current political climate all over the world has witnessed a shift in attention to the social media. For instance; the recently concluded 2019 general elections witnessed a remarkable use of social media as a political communication tool in Nigeria. Indeed, several aspirants especially at the presidential level engaged robustly on social media campaigns.

Three major issues underline the tremendous use of social media tools during the 2019 general elections. Firstly, it reflects a global trend towards "internet elections" or "e-electioneering". Around the world, rapidly expanding access to the internet, increased availability of internet ready smart-phones and other communication devices, as well as the evolution of web-based new media - personal websites, social networking sites, blogs, enewsletters, have redefined methods of political communication, leading to a significant shift towards the use of social media in the electoral process. Previously, network television and newspapers dominated coverage of electioneering and were the primary sites of election-related information. But today, the social media has become a major election information sharing platform globally. Because of its ease of use, speed, and reach, social media is revolutionizing the efficiency of election administration, coverage and reporting.

The second issue that underlines the use of social media in Nigeria's 2019 elections is the tendency of some Nigerian politicians to tap the opportunities offered by the social media for on-line campaigning. During the 2019 general elections, many politicians, particularly the presidential aspirants, used social media tools to connect with voters and constituents. Facebook and Twitter appear to be the most widely used social media platforms by the politicians. Presidential aspirants like Atiku Abubakar, Tony Moghalu, Oby Ezekwesili, Sola Sowore, among others all had Twitter and other social media accounts. Political parties also maintained Facebook accounts. Social media offered politicians and their parties the opportunity to broadcast messages and recruit a huge number of volunteers to support their campaign.

The third issue that underscores the use of social media in Nigeria's 2019 general elections is the tendency of the Nigerian civil society and the electorate to take up social media as a tool for improving the efficiency of election observation. Prior to the conduct of the 2019 elections, elections in Nigeria had been largely flawed by vote rigging and other electoral malpractices.

The 2019 general elections offered a unique context and opportunity to examine the use of social media in elections, especially the usefulness and applicability of social media in the electoral environment. Although it seems obvious that social media contributed in no small measure to the success of the 2019 elections, it is pertinent to understand specifically how particular stakeholders in the 2019 elections, like INEC, politicians/political parties, the electorate, and Civil Society Organizations (CSOs) used the social media during the elections and the impacts these had on the elections.

In recognition of the ever increasing role of the social media in election, many world leaders now communicate and update their citizens via twitter, facebook and others. Infact, as earlier mentioned, Mr Donald Trump, the President of the United States of America constantly "tweet" and "retweet" on tweeter and he is even regarded as "being too social media savvy". In Nigeria, President Mohammadu Buhari, though not a social media savvy president recognises the influence and impact of social media. Consequently, he appointed Ms. Lauretta Onochie and Bashir Ahmad to manage his social and new media platforms. 


\section{Theoretical Framework}

\subsection{Agenda Setting Theory}

The theoretical framework of this study is limited to the Agenda Setting Theory. The Agenda setting theory of the media according to Zhu and Blood (1997:111, cited in Owoyemi, 2018), "is the process whereby the news media lead the public in assigning relative importance to various public issues". This is because the action of the media is towards influencing people's perception of what is important, acceptable, or desirable. Attention is drawn to certain aspects of reality and away from others, thus influencing people in terms of what to think.

This agenda-setting function of news casting can be achieved deliberately or accidentally by the size of headlines, order of appearance, choice of words, and length of coverage and this is possible because of the active audience which are conceived as selective in their programming choices and interpretation, motivated by different demands, and resistant to direct media influence; in contrast to the concept of mass audiences whom many perceived as passive and easily swayed. The concept represents a new way of thinking about audiences and their relationship to media communication. Folarin (1998:68) in his own view notes that "Agenda setting implies that the mass media predetermines what issues are regarded as important at a given time in a given society". In Folarin's submission, the media through its educative and enlightenment functions brings to light different issues of importance during elections. Elections are paramount to the success of any democratic engagement in any country. Different media are usually employed by politicians, civil society groups, electoral bodies, government and its agencies in the quest for successful free and fair elections.

Agenda setting does not ascribe to the media the power to determine what people actually think but it does ascribe to them the power to determine what people are thinking about. They set the agenda for political campaigns. Daniel (2003:121) argues that:

The mass media force attention to certain issues and they build-up public images of political figures. They are constantly presenting objects suggesting that individuals in the mass media should think about, know about and have feelings about.

The rationale behind adopting the Agenda Setting Media Theory in this study is because it explains the role or function of the media in determining public agenda before, during and after elections. It further describes the influence of the media in molding and shaping the opinion of the public towards some topical issues, of which election is paramount. In fact, the main trust of the agenda setting theory is that the mass media set agenda on the burning issue in the society for public discourse.

According to Folarin (1998:68), the elements involved in agenda setting include:

i. The quality or frequency of reporting

ii. Prominence given to the reports - through headline, display, pictures and layout in newspapers, magazines, films, graphics or tuning on radio and television

iii. The degree of conflict generated in the reports; and

iv. Cumulative media specific effects overtime.

The media, most especially social media, through the above elements can colour events by using them in a particular way or refusing to use them at all. This significantly shaped the conduct and the outcome of the 2019 Nigeria's general elections.

4.2 Presentation and Discussion of Findings Research objective 1: Which stakeholders reached you through the social media during the 2019 General Elections?

Table 1: Distribution of opinions of respondents about stakeholders that reached them through the social media during the 2019 general elections

\begin{tabular}{lll}
\hline Stakeholders & Frequency & Percentage \\
\hline INEC & 95 & 80.5 \\
Political parties & 87 & 73.7 \\
Aspirants/contestants & 56 & 47.4 \\
Civil society organizations & 47 & 39.8 \\
Others & 35 & 29.6 \\
\hline
\end{tabular}

Source: Fieldwork, 2019

Table 1 above revealed that $80.5 \%$ of the respondents said the Independent electoral Commission (INEC) reached out to them through the social media, $73.7 \%$ of the respondents indicated that political parties reached out to them through the social media during the 2019 general elections in Nigeria, $47.4 \%$ of the respondents opined that the aspirants and contestants reached out to them through the social media during the 2019 general elections, $39.8 \%$ of respondents said civil society organizations reached out to them through the social media during the 2019 general elections while $29.6 \%$ of respondents said other stakeholders apart from those identified above reached out to them through the social media during the 2019 general elections. 
Research Objective 2: Did the social media contribute to the peaceful and successful conduct of 2019 General Elections?

Table 2: Distribution of respondents' opinions on the contributions of social media to the peaceful and successful conduct of the 2019 elections

\begin{tabular}{|c|c|c|c|}
\hline Item & $\begin{array}{l}\text { Total no } \quad \text { of } \\
\text { respondents }\end{array}$ & $\begin{array}{l}\text { Responses (\%) } \\
\text { Yes }\end{array}$ & No \\
\hline $\begin{array}{l}\text { Social media contributed to the peaceful } \\
\text { conduct of the } 2019 \text { general elections? }\end{array}$ & 120 & $\begin{array}{l}96 \\
(80 \%)\end{array}$ & $\begin{array}{l}24 \\
(20 \%)\end{array}$ \\
\hline
\end{tabular}

Source: Fieldwork, 2019

Table 3: Distribution of respondents' opinions on how the social media contributed to the peaceful and successful conduct of the 2019 elections in Nigeria

\begin{tabular}{lll}
\hline Category & Frequency & Percentage \\
\hline Provided information about voters card & 88 & 91.6 \\
Provided information about date of elections & 82 & 85.4 \\
Provided information about voting centres & 69 & 71.9 \\
Provided platform for campaigns & 56 & 58.3 \\
Peace education & 47 & 48.9 \\
\hline
\end{tabular}

Source: Fieldwork, 2019

Table 2 above indicated that $80 \%$ of the respondents' stated that social media contributed to the peaceful and successful conduct of the 2019 general elections in Nigeria. Similarly, table 3 outlines respondents' opinions on how the social media contributed to the peaceful and successful conduct of the 2019 general elections. $91.6 \%$ of the respondents' opined that social media provided information about voters card to the Nigerian electorates, $85.4 \%$ said it provided information on the dates for elections, $71.9 \%$ said the social media provided information on voting centres, $58.3 \%$ of respondents said the social media provided platform for campaigns while $48.9 \%$ of respondents said the social media was used for peace education.

Research Objective 3: How the social media can be used to add value to subsequent elections in Nigeria.

Table 4: Distribution of opinions of respondents on how social media can be used to add value to subsequent elections in Nigeria

\begin{tabular}{lll}
\hline Category & Frequency & Percentage \\
\hline $\begin{array}{l}\text { It can reduce electoral fraud as riggers can be recorded and uploaded online for } \\
\text { everyone to see. }\end{array}$ & 77 & 92.7 \\
\hline It can bring transparency through online transmission and announcement of results & 72 & 86.7 \\
\hline It can reduce cost of campaigns through online campaigns by aspirants & 56 & 67.4 \\
\hline $\begin{array}{l}\text { It can be used by Nigerians at home and in Diaspora to easily and quickly interact } \\
\text { with aspirants }\end{array}$ & 47 & 56.6 \\
\hline It can increase citizens participation in the political processes & 35 & 42.1 \\
\hline Source: Fieldwork, 2019 & &
\end{tabular}

Table 4 above showed that $92.7 \%$ of respondents said the usage of social media in subsequent elections in Nigeria can lead to reduction in electoral fraud since voters can record incidences of vote rigging and upload same online to serve as deterrent to election riggers. Also, $86.7 \%$ of respondents said the social media can bring the much needed transparency into the electoral process in Nigeria through online transmission and announcement of results. $67.4 \%$ of respondents opined that the use of social media can reduce the cost of campaigns for both aspirants and political parties during elections. $56.6 \%$ of respondents said social media can be used by Nigerians at home and in Diaspora to easily and quickly interact with aspirants and contestants during elections while $42.1 \%$ of respondents said the social media can increase citizens' participation in the political processes.

\subsection{Discussion of Findings}

The significant use of social media during the 2019 general elections in Nigeria was a result of three key factors: the tendency of election stakeholders in Nigeria to follow the global trends in the use of social media as a political communication tool; the tendency of Nigerian politicians and political parties to tap into the opportunities offered by social media to reach and engage their constituents and voters; and lastly the tendency to use the social media tools to improve the efficiency of election observation. Findings revealed that the key stakeholders in the Nigerian electoral process (the INEC, Politicians/political parties, the electorate, and the CSOs) made extensive use of social media during the 2019 general elections. Each of these stakeholders used the social media to achieve a number of goals and objectives. INEC used social media basically to broadcast messages on the elections and receive feedbacks from the public on their experience with the process. Politicians/political parties used the social media to reach out to the voters and canvassed for vote and support. 
The electorates used social media to report their experiences and receive election related information, while the CSOs used the social media to mobilize and educate the electorates as well as to cover and report their observation of the electoral process.

There are many questions about the reliability of the information collected and shared through the social media by "citizen journalists", especially in respect of online posting and announcement of election results. Bearing in mind the fact that some of these citizen-journalists might be people with partisan interests, it is difficult to affirm the accuracy of the reports without subjecting them to a systematic verification process. Information shared through the social media during the 2019 general elections passed through only little or no form of vetting or verification which led to misinformation being circulated. Going by the outcomes of the 2019 general elections, it can be argued that Nigeria still have fundamental issues of flawed and fraudulent elections, hence, the challenges that lie ahead are many and daunting. Between now and the next general elections in 2023, far-reaching electoral, political and economic reforms are needed to help consolidate the modest gains made in 2019 elections and launch the country on the path of permanent and sustainable electoral change.

\section{Conclusion}

This study investigated the usage and impacts of social media on the 2019 general elections in Nigeria. Findings revealed that stakeholders such as INEC, political parties, aspirants and civil society organisations reached out to the respondents through social media. Also, respondents noted that social media contributed to the peaceful and successful conduct of the 2019 general elections in Nigeria; Finally, respondents submits that the social media can be used to add value to subsequent elections in Nigeria because it has the potential to reduce electoral fraud, reduce cost of campaigns, enshrine transparency in the electoral process among others.

\section{Recommendations}

Based on findings of this study, the following are therefore recommended:

1. The Electoral Act should be reviewed to provide specific guidelines on the use of social media in Nigeria's future elections.

2. INEC, civil society organizations and security agencies should establish modalities to systematically verify information reported by citizen observers through the social media.

3. INEC should establish a social media tracking center to monitor, collate, and interpret trends and reports during elections.

\section{References}

Aleyomi, M. \& Ajakaiye, O (2014) The Impact of Social Media on Citizens' Mobilization and Participation in Nigeria's 2011 General Elections ResearchGate Journal. Vol.17, No.2, pp.31-52 31 https://www.researchgate.net/publication/305991599

Amuchie, M. (2012). Social Media Critical to Success, says Jega. from http://www.businessdayonline.com/NG/index.php/news/111-politics/37726-social-media-critical-tosuccess-of-2011-elections-says-jega Retrieved May 01, 2019

Arthur, C. (2012). Encouraging Political Participation in Africa. <http://www.issafrica.org Retrieved March 18, 2019

Baekdal, T. (2008). The Mobile Internet Revolution is Here, <http://www.baekdal.com/ trends/mobile-internetrevolution>. Retrieved May, 2019

Bamgbose, J. (2012) Media as a Mediator. In Thum, U. (ed) Peace Journalism. Ibadan: JDPC.

Clark, J. and Aufderheide, P. (2009). Public Media 2.0: Dynamic, Engaged Publics. Washington, DC: Center for Social Media, American University http://www.centerforsocialmedia.org/sites/default/files/whitepaper.pdf Retrieved February 12, 2019

Daniel, A. A. (2003). Agenda Setting For Political Communication: A Nigerian Experience. UNILAG Communication Review, 4(1):117-132

Folarin, B. (1998). Theories of Mass Communication: An Introductory Text. Ibadan: Stirling Horden Publishers Nig. Ltd.

Ibrahim, J. and Ibeanu, O. (2009). Direct Capture: The 2007 Nigerian Elections and Subversion of Popular Sovereignty. Lagos: Center for Democracy and Development.

Internet Live Stats (2014). Internet Users by Country, $2014<\mathrm{http}: / / \mathrm{www}$. internetlivestats.com/internet-users-bycountry> Retrieved April 12, 2019.

Jones, S. and Fox, S. (2009). Generations Online in 2009: Pew Internet and American Life Project $<$ http://www.floridatechnet.org/Generations Online in 2009 .pdf $>$ Retrieved April 12, 2019

Kaplan, A. M. (2010). Users of the World, Unite! The Challenges and Opportunities of Social Media. Business Horizons, 53(1):59-68.

Kaur, S and Kaur, M. (2013), Impact of Social Media on Politics. Gian Jyoti E-Journal, Volume 3, Issue 4 ISSN 
2250-348X www.gjimt.ac.in/GianJyotiE-Journal.htm 23

Kuusik, N. (2015) The Role of the Media in Peace Buildiing, Conflict Management and Prevention. www.eir.infu//theroleofmediainpeacebuilding, downloaded on March 25, 2015.

Mejabi, O.V. and Fagbule, J.O. (2014). Citizen Engagement with Social Media by State Governors in Nigeria. Afr J. of Comp \& ICTs, 7(4), 46-50.

Owoyemi, A (2018). Print Media Contribution To Prevention Of Electoral Violence In The 2015 General Election In Nigeria. Being M.A Dissertation submitted to the University of Ibadan, In partial fulfillment of the requirements for award of Masters in Language and Communication Art.

Sweetser, K. D. and Lariscy, R. W. (2008). Candidates Make Good Friends: An Analysis of Candidates ${ }^{\text {ee }}$ Uses of Facebook, International Journal of Strategic Communication, 2(3), 175-198 